\title{
Analyzing Actors' Engagement in Sustainable Energy Planning at the Local Level in Ghana: An Empirical Study
}

\author{
Hassan Qudrat-Ullah ${ }^{1, *(D)}$, Mark McCarthy Akrofi ${ }^{2}$ (D) and Aymen Kayal ${ }^{3}$ \\ 1 School of Administrative Studies, York University, Toronto, ON M3J 1P3, Canada \\ PAUWES, Tlemcen 13000, Algeria; macakrofi@gmail.com \\ $3 \quad$ KBS, KFUPM, Dhahran 31261, Saudi Arabia; akayal@kfupm.edu.sa \\ * Correspondence: hassanq@yorku.ca; Tel.: +1-416-736-2100
}

Received: 15 March 2020; Accepted: 16 April 2020; Published: 18 April 2020

check for updates

\begin{abstract}
Actors play a crucial role in sustainable energy development yet interaction in different contexts is an area that has not received much scholarly attention. Sustainable energy transitions theories such as the Multi-Level Perspective, for instance, have been criticized for not describing precisely the nature of the interactions between actors and institutions within socio-technical systems. The goal of this study was to empirically examine local actors' engagement and its impact on the planning and implementation of sustainable energy initiatives in the villages and remote areas in Ghana. Using the mixed methodology approach, interviews were performed, focus discussion groups were held, and archival data were collected, and social network modeling and case study analysis was performed. Our findings showed that sustainable energy development at the local level depends on an interplay between local government agencies, Non-Governmental Organizations (NGOs), central government agencies, local communities, and private sector organizations. Despite being the focal point at the local level, local government involvement in sustainable energy planning is limited. In the case of Ghana, sustainable energy planning remains centralized and is manifested in a low level of awareness of local actors on national energy plans. The implication for decision makers is that energy planning functions should be devolved to the local government. Such devolution is expected to ensure the integration of sustainable energies into local government plans for the well-coordinated implementation and effective monitoring of sustainable energy projects.
\end{abstract}

Keywords: sustainable energy planning; actor analysis; decentralization; local government; socio-technical systems; renewable energy

\section{Introduction}

Decentralized systems comprising off-grid and mini-grid solar photovoltaics (PVs) and the deployment of Liquefied Petroleum Gas (LPG) and natural gas are the most cost-effective solutions for enhancing energy access in sub-Sahara Africa (SSA) [1]. The provision of such decentralized systems creates the need to involve local governments in the development and utilization of sustainable energy sources. The role of local governments in Sustainable Energy Transitions (SETs) and climate action has gained increased attention in the literature. For example, Melica et al. [2] analyzed how regions and provinces support local authorities in energy-climate planning, whilst Mey, Diesendorf, and MacGill [3] examined the motivations, opportunities, and challenges of local governments in renewable energy development. Similarly, Lammers and Hoppe [4] analyzed various institutional settings for renewable energy planning at the local level, whilst Johnson et al. [5] explored opportunities for citizen participation in local/county level energy planning in Kenya. All these studies point to the 
fact that local level initiatives are important in engineering sustainable energy transitions, and hence, there is a need to understand how local governments and local actors are engaged and how they can facilitate such processes. Sgouridis and Csala [6] define SET as a process by which society replaces all major fossil fuel primary energy inputs with sustainably renewable resources. Steg, Perlaviciute and van der Werff [7] explain that a sustainable energy transition is characterized by a dominance of renewable energy sources in future energy systems. An energy system refers to all components related to the production, conversion, delivery, and usage of energy [8]. Lockwood et al. [9] identified energy providers, policymakers, and users of energy as the three main actors in the energy system.

From a theoretical perspective, Geels [10] identifies three main interrelated elements of a socio-technical system: (i) a network of actors and social groups; (ii) formal, cognitive, and standardized rules that guide their activities; and (iii) physical and technical features, such as infrastructure. Socio-technical systems comprise natural and built elements (energy infrastructure or resources) as well as social and institutional elements, such as organizations and individuals [11,12]. The importance of actors and agencies in such systems has been elaborated in several studies. Fischer and Newig [13] present a comprehensive summary of such studies in their systematic review of the importance of actors and agencies in sustainability transitions. Cahn [14] defines actors as formal or informal individuals or groups that influence the formulation and implementation of solutions to address public problems. Shannon [15] adds that these individuals or groups are directly or indirectly associated with or affected by the policy process and that they can include governments, NGOs, businesses, communities, and Civil Society Organizations (CSOs). In the context of renewable energy solutions, participation and ownership of local communities are critical to the implementation and sustainable operations of the projects. Given the diverse nature of actors and their interests, multi-criteria analysis is often used in formulating courses of action for sustainable energy development in different countries. Such an analysis is to ensure that sustainable energy decisions reflect the interests of various actors since they play a vital role in ensuring the successful implementation of energy decisions. For instance, Mirjat et al. [16] and Tsoutsos et al. [17] employed the multi-criteria method to analyze sustainable energy planning in Pakistan and the island of Crete, respectively. The importance of stakeholders in the context of renewable energy projects is emphasized in a comprehensive review by Pohekar and Ramachandran [18].

The importance of actor analysis is also highlighted in critiques leveled against dominant SET theories such as the Multi-Level Perspective (MLP). The MLP has been criticized because it fails to precisely describe the nature of interactions between actors and institutions within socio-technical systems [9]. These criticisms raise the need to research the interplay between actors in various socio-technical systems, given the premise that interactions between actors are crucial to sustainability transitions [13]. This study, therefore, is focused on the actors' engagement at the district/local level in Ghana.

Districts in Ghana are local government bodies through which national policies are translated into action for development. Local governments act as key media for coordinating and implementing effective local energy and environmental policies [19]. They understand where challenges with regards to sustainable energy come from; they can assess local renewable energy resources and how these resources can be optimized; and they can identify the strengths, weaknesses, opportunities, and threats with regards to renewable energy development in their respective jurisdictions [20]. Despite these crucial roles that local governments can play in sustainable energy development, very little is known about the holistic state of energy at the local/district level in Ghana, hence making effective planning for sustainable energy issues impossible [21]. Information on the types of actors, the nature of their engagement, and the mechanisms by which they plan and implement sustainable energy projects are generally lacking.

We attempt to resolve the above challenge by addressing the research question "How do actors' engagement in sustainable energy planning and implementation affect sustainable energy development at the local government level in Ghana?", applying the mixed methodology approach, where social 
networking analysis (quantitative data analysis) and in-depth interviews and case analysis (qualitative data analysis) are performed to study the local actors' engagement and interactions impacting the planning and implementation of sustainable energy initiatives. The novelty of this study lies in the fact that it is perhaps the first attempt to provide comprehensive insights into sustainable energy planning and implementation at the local level with specific reference to local government participation in sustainable energy development in the Wa Municipality in Ghana. The results of this study are expected to promote a comprehensive understanding of local government participation in sustainable energy issues and provide a basis for integrating sustainable energies into local government plans. In Section 2, we present a review of the relevant literature. In Section 3, we describe the methodology. Section 4 presents the results and discussion. Finally, in Section 5, we draw some conclusions and discuss the limitations and some future research possibilities.

\section{Literature Review}

Local governments have long been recognized by central governments as important actors in the implementation of energy systems and policy because of their strong reach and engagement abilities in their communities. For example, the UK government, since two decades ago, has recognized the role of local authorities in catalyzing community action on climate change and energy issues and has used it very effectively $[22,23]$. Localized distributed solutions using local innovative approaches were found to be more effective than the centralized top-down interconnected energy systems [24]. In some instances, it was the local governments who were leading the way in the implementation of initiatives for renewable energy, even without the central government's direction and support. Mey et al. [3] describe how community renewable energy groups (CRE) in Australia have established operating CRE projects with the help of the local government alone.

Tait and Euston-Brown [25] studied the three African nations of Ghana, Uganda, and South Africa and found that the extent to which formal multilevel governance arrangements either enabled or constrained the ability of African municipalities to proactively engage with low carbon development goals depended on how much the country's decision making was centralized. Their analysis pointed to the relevance of building a more collaborative model of governance that engages local governments and multiple actors, rather than relying solely on the central government to intervene. They argue that to successfully implement renewable energy goals, it is essential that an empowered local government has the competencies, financial resources, and political will to drive local action [25]. Thus, local actors appear to play a critical role in the success of socio-technical transition initiatives such as the development and deployment of renewables.

A socio-technical transition (STT) denotes a change of the socio-technical system from one relatively stable state to another [26], and the systems are made up of several different areas across industry, technology, and politics [27]. SETs, therefore, reflect new technologies and changes in user practices and policies. Foxon [28] posits that a low carbon transition, for instance, is characterized by changes in how we use energy, development, and the deployment of cleaner energy technologies, as well as a change in the industrial mix within national or global economies. These elements are inter-linked within a socio-technical system, hence making transitions uneasy [26], with lock-in mechanisms "that relate to sunk investments, behavioral patterns, vested interests, infrastructure, favorable subsidies and regulations" [29] p. 495. Hence, it becomes challenging for new technologies to succeed because they are associated with regulations, user practices, and infrastructure [9]. The fundamental tenet of this theory is that the sustainable energy transition is a function of social, technological, and political factors in any given society.

In developing the STT theory further, the multi-level perspective was introduced [26,30]. According to Geels and Schot [31], in MLP, transitions are understood as results of a configuration between developments at multiple levels within the socio-technical system. Transition to a new socio-technical system thus comes as a result of interactions between three levels: regimes, niches, and landscapes [26,30-32]. According to Smith, Voß, and Grin [33], socio-technical regimes are a mainstream and highly institutionalized 
way of realizing societal functions. Geels [26] refers to the socio-technical regime as the semi-coherent set of rules carried by different social groups that directs and coordinates the activities of different actors and, by so doing, ensures the stability of socio-technical configurations. Niches relate to technical innovations that drive socio-technical transitions. Research and Development (R\&D) is thus an essential component of niches. However, Geels [26] adds that supportive social networks and processes such as learning by doing are vital. Niches and regimes are both situated within a landscape. The landscape level is the peripheral structural setting [9] or context for the interaction of actors [26] within which regimes and niches operate. They are external factors that affect both regimes and niches. Examples include fuel prices, economic factors such as inflation, conflicts, emigration, broad political alliances, and environmental pressures [31,33]. Interactions within and between these three different levels (regime, niche, and landscape) are what bring about the transition [29]. Papachristos et al. [32] explain that the stability of a regime can be disturbed by pressures from the external environment and innovations developed in niches within a regime. Social groups within a regime, for instance, can mount an internal pressure in response to technical innovations within niches or events from the external environment. Lockwood et al. [9] cite an example, that the acknowledgment of climate change can be one of such responses.

The STT theory recognizes society as a socio-technical system comprising regimes, niches, and landscapes that interact to bring about a SET. A vital strength of the STT lies in the fact that it points out the high complexity and dynamic character of transitions as well as the need for actively using policy to manage transitions [9]. The theory is, however, criticized, in that despite its recognition of policy playing a central role in transitions, it fails to discuss in detail the political dimensions of decision making [34-36]. The MLP has also been criticized, in that it fails to precisely describe the nature of interactions between actors and institutions within the various levels (niches, landscapes, and regimes); hence, its explanatory power is limited [9]. Foxon [28] attempted to further expand the socio-technical transitions approach. He adopted a "co-evolutionary" approach [9] to develop a framework for the analysis of low carbon energy transitions. Foxon [28] posited that transition is the result of interactions between five main elements: eco-systems, technology, institutions, business strategies, and user practices. However, Foxon's [28] framework has also been criticized because "it does not provide much detail on what is contained within each system, and importantly, what is happening and who is involved in the interactions between them" [9] p. 12. Therefore, this research will attempt to make an important contribution by (i) considering districts as socio-technical systems (using the case of Ghana) and (ii) identifying the actors and the nature of the interactions among them.

Districts are the lowest level within Ghana's three-tier public sector system, which comprises central, regional, and local/district levels [37]. As local government bodies, "districts are corporate bodies, perform public functions within their jurisdictions, have their political leadership (often elected) and, prepare and approve their budgets" [37] p. 11. Each district has a general assembly (hereafter known as the Assembly), which is the highest decision-making body of the district and performs deliberative, legislative, and executive functions. Each district also has a District Chief Executive (DCE) who represents the central government and is responsible for the daily performance of the supervisory and managerial functions of the Assembly. Each district has a member of parliament (MP) who represents electoral constituencies within the district and serves as the liaison between the District Assembly and the parliament. As socio-technical systems, districts also have niches. Geels [26] adds that supportive social networks are equally vital. A major function of the districts as defined in Section 10 (3) of the Local Government Act, 1993 (Act 462) is to "initiate, sponsor or carry out such studies as may be necessary for the discharge of any of the functions conferred by Act 462 or any other enactment" [38] p. 3462. Each district also has decentralized departments that are responsible for providing the needed technical expertise for the development of the district. The districts can liaise with higher education institutions, private sector companies, and incumbent energy firms to undertake research that will speed up sustainable energy access within their jurisdictions. 
On the other hand, national energy policies and legal and regulatory frameworks for sustainable energy sources will impact significantly on sustainable energy initiatives at the district level. Environmental conditions vary among various regions and, thus, among the districts of Ghana. Climate change effects manifest differently in different parts of the country. Each district thus has the task of responding to these environmental pressures. The level of threat posed and the extent of impact felt by the inhabitants can also result in internal tensions within the regime, as postulated by Papchristos et al. [32]. This pressure can eventually lead to regime change, where the elected officials are voted out for failing to meet the expectations or needs of the people. Actors are often categorized by heterogeneity, which may prove problematic [13]. However, such heterogeneity enables multi-actor collaborations that result in resource pooling, thereby increasing the resources available to actors $[39,40]$.

Local actors are vital to the success of sustainable energy projects [41]. For instance, in large-scale projects, local actors can stimulate behavioral changes, engender local acceptability, develop energy infrastructure, and aid in effective policy formulation [13]. Izutsu et al.'s [41] study demonstrates how "driving actors" facilitated the implementation of a renewable energy project in the city of Bizen, Japan. They explained that local people are actively involved in research and development (R\&D), promoting (through education/dissemination) and implementing pilot projects. The importance of local actors in sustainable energy development is also evident in Germany's renewable energy sector, where local/regional groups own about half of the country's renewable energy capacity, with the formation of more than nine hundred energy cooperatives [42]. In Australia, Mey, Diesendof, and MacGill [3] found that local governments possess a high awareness of the renewable energy (RE) needs of their communities and that they play crucial functions in RE development, such as through information sharing, funding feasibility studies, and facilitating community energy projects. A study of stakeholders' influence on the development of community RE in seven European countries (Finland, Scotland, Germany, Norway, Ireland, Sweden, and Northern Ireland) found that local level actors, especially the local communities, were very supportive stakeholders for the success of community RE [43]. A comprehensive understanding of how such actors function and the interrelationship among them is pertinent to engineering sustainable energy transitions from fossil-based energy consumption to the use of sustainable energy. The lack of such an understanding in Ghana has been identified as a major challenge to sustainable energy development.

Therefore, considering districts as socio-technical systems, the goal of this study was to identify and analyze the interactions among various actors at the local level with regards to the promotion, development, and utilization of sustainable energies. The nature of sustainable energy projects and the engagement of NGOs and private sector actors at the local level are also examined. An increased understanding of how actors interact in and with a socio-technical system is expected to contribute to the theoretical perspectives on the MLP and the co-evolutionary approach.

\section{Methodology}

To address our research question, we applied a mixed-methods approach [44]. The research dealt with "who is involved and how" with regards to sustainable energy development. Hence, the mixed-method approach was suitable because it combines both quantitative and qualitative approaches, which allowed for analyzing actors' involvement using social network analysis (quantitative) and in-depth analysis, with a qualitative description of how various actors were involved in the planning and implementation of sustainable energy initiatives at the local level. Figure 1 displays the major methodological steps. 


\begin{tabular}{|c|c|c|c|c|}
\hline $\begin{array}{l}\text { Step 1: Establishing } \\
\text { the study setting }\end{array}$ & $\begin{array}{l}\text { Step 2: Selection of } \\
\text { study participants }\end{array}$ & $\begin{array}{l}\text { Step 3: Data } \\
\text { collection }\end{array}$ & $\begin{array}{l}\text { Step 4: Data } \\
\text { analysis }\end{array}$ & $\begin{array}{l}\text { Step 5: Presentation } \\
\text { fo results }\end{array}$ \\
\hline $\begin{array}{l}\text { - This was done } \\
\text { to understand } \\
\text { the case study } \\
\text { site's } \\
\text { demographics, } \\
\text { sustainable } \\
\text { energy } \\
\text { initiatives, and } \\
\text { local actors } \\
\text { present. Wa } \\
\text { municipality } \\
\text { was selected } \\
\text { for the study. } \\
\text { - This } \\
\text { municipality } \\
\text { has benefitted } \\
\text { from } \\
\text { sustainable } \\
\text { energy } \\
\text { projects. }\end{array}$ & $\begin{array}{l}\text { - Various } \\
\text { agencies/actors } \\
\text { involved in } \\
\text { sustainable } \\
\text { energy } \\
\text { initiatives in } \\
\text { the } \\
\text { municipality } \\
\text { were } \\
\text { purposively } \\
\text { selected } \\
\text { through a } \\
\text { prelimary } \\
\text { literature } \\
\text { search, a visit } \\
\text { to the } \\
\text { municipal } \\
\text { planning unit, } \\
\text { and snow- } \\
\text { balling. } \\
\text { - } 13 \text { agencies and } \\
2 \text { local } \\
\text { communities } \\
\text { were selected. }\end{array}$ & $\begin{array}{l}\text { - Primary data } \\
\text { were collected } \\
\text { from various } \\
\text { actors using } \\
\text { interviews and } \\
\text { Focus Group } \\
\text { Discussions } \\
\text { between April } \\
\text { and June } 2019 \text {. } \\
\text { - Interview guides } \\
\text { with open-ended } \\
\text { questions were } \\
\text { used to collect } \\
\text { data from focal } \\
\text { persons at the } 13 \\
\text { agencies } \\
\text { selected. An } \\
\text { FGD guide was } \\
\text { used to conduct } \\
\text { two FGDs in the } \\
\text { selected } \\
\text { communities. }\end{array}$ & $\begin{array}{l}\text { - Field data were } \\
\text { transcribed and } \\
\text { imported into the } \\
\text { primary unit of } \\
\text { the ATLAS.ti } \\
\text { software for } \\
\text { analysis. A data } \\
\text { matrix was } \\
\text { generated for } \\
\text { Social Network } \\
\text { Analysis. } \\
\text { - The matrix was } \\
\text { based on } \\
\text { magnitude } \\
\text { (frequent } \\
\text { exchange of } \\
\text { information) and } \\
\text { directionality } \\
\text { (from who and } \\
\text { to whom } \\
\text { information is } \\
\text { directed). } \\
\text { - The matrix was } \\
\text { imported into the } \\
\text { NETDRAW } \\
\text { component of } \\
\text { the UCINET } 6 \\
\text { software for } \\
\text { analysis. }\end{array}$ & $\begin{array}{l}\text { - Network } \\
\text { visualization in } \\
\text { NETDRAW was } \\
\text { used to present } \\
\text { the relationships } \\
\text { between various } \\
\text { actors. } \\
\text { - For the interview } \\
\text { data, Codes with } \\
\text { their } \\
\text { corresponding } \\
\text { quotations were } \\
\text { generated in the } \\
\text { ATLAS.ti } \\
\text { software, and the } \\
\text { patterns were } \\
\text { used for analysis. } \\
\text { - Results were } \\
\text { discussed and, } \\
\text { where necessary, } \\
\text { quotations were } \\
\text { presented } \\
\text { verbatim to } \\
\text { support the } \\
\text { findings }\end{array}$ \\
\hline
\end{tabular}

Figure 1. The major methodological steps (Source: Authors' conception).

\subsection{Study Setting (Step 1)}

The study was conducted in the Wa municipality of Ghana. The capital of the municipality is Wa. It was selected based on the fact that it is one of the oldest municipalities in Ghana and has benefitted from several sustainable energy projects. The total population of the municipality is 107,214 persons, with growth rates of $2.7 \%$ and $4 \%$ for the rural and urban areas, respectively [45]. The principal source of energy for lighting in the entire municipality is electricity from the national grid. Seventy-two percent of dwelling units derive their source of lighting from the national grid, $15.1 \%$ use flashlights/torches, and $10.9 \%$ use kerosene lamps, while $0.1 \%$ use crop residue and firewood [45]. Many of the rural population still rely on flashlights/torches (31.5\%) and kerosene lamps (18.4\%) for lighting [45]. Only $0.2 \%$ of dwelling units in the entire municipality use solar energy and gas lamps. Hence, sustainable/renewable energy usage for lighting in the municipality is extremely low. Given the unreliable nature of power supply from the main grid and the strong potential for solar energy in the municipality [46], the current low level of sustainable energy utilization provides an opportunity and a potential market for investment into renewable energy sources such as solar.

With regard to cooking, the dominant sources of fuel are charcoal (55.2\%) and wood $(22.9 \%)$. Only $16.3 \%$ of households use LPG [45]. The proportion of households using charcoal for cooking is higher for urban areas $(65.7 \%)$ than rural areas $(28.9 \%)$, while wood is predominantly used by rural households $(56.2 \%)$ rather than urban households $(9.8 \%)$. There is a need for the development and utilization of modern energy for cooking. Since the Municipal Assembly (which is the local government body) is responsible for formulating and implementing developmental projects, it is better positioned to spearhead the development and utilization of sustainable energy by the households, given that all districts have the same administrative structure as stipulated by the Local Government Act (Act 462) of 1994 and that the findings from this study can be fairly generalized for other municipalities in Ghana.

\subsection{Study Design and Selection of Participants (Step 2)}

The study employed a case study design [44]. This design enabled the researchers to collect in-depth information about the engagement of various actors in the sustainable energy sector in the Wa municipality. Participants of the study were selected using purposive sampling. This non-probability 
sampling technique was ideal for the study because we required information from only actors who were engaged in local governance and sustainable energy issues in the municipality and thus possessed the in-depth knowledge needed for the study. The selection of participants was done through a preliminary literature search, initial data collection, and snowballing. The researchers first conducted a literature search on the actors involved in renewable/sustainable energy initiatives in the municipality. This search focused on institutional arrangements in key policy documents as well as a review of NGOs that are currently working on sustainable energy issues in the municipality. Subsequently, a visit was made to the Municipal Planning and Coordinating Unit (MPCU). A list of all actors and agencies working on sustainable energy issues was requested from the Municipal Development Planning Office. This list was reconciled with the list obtained from the literature search to obtain the list of participants for the research. In the course of data collection, the respondents were asked to mention other actors that they engage in sustainable energy issues in the municipality. This process led to the emergence of some new actors who were not captured in the initial list generated. In all, thirteen agencies and two local communities were involved in the study.

\subsection{Data Collection (Step 3)}

Interviews and Focus Group Discussions (FGDs) were the main methods used in gathering data for the study. The data collection was carried out between April and May 2019 in the Wa municipality. Various heads of departments and focal persons from the institutions were the points of contact, and face-to-face interviews were conducted with them to obtain the needed data and information. The corresponding instrument for data collection was the interview guide. The guide entailed a series of open-ended questions that served as the basis for discussion between the researcher and the respondents. FGDs were used for collecting qualitative data from two beneficiary communities (Busa and Guropisi) of sustainable energy projects. Two FGDs (comprising between six and eight people) were conducted in each community. The FGDs consisted of members of community-level committees that were formed to oversee the implementation and management of the projects. The instrument used for the FGDs was the FGD guide. The guide entailed a list of open-ended questions that the researcher used in facilitating the discussions.

\subsection{Data Analysis and Presentation of Results (Steps 4 and 5)}

Social Network Analysis (SNA) was used in analyzing the engagement of various actors in sustainable energy development in the municipality. Cronin [47] p. 4 defined SNA as "a set of techniques for identifying and representing patterns of interaction among social entities, be it individuals, groups, organizations or social artifacts". SNA is based on graph theory, and it employs graphical techniques to analyze the nature and pattern of relationships among different entities. These entities (in this case, the actors under study) are represented as points, which are known as nodes or vertices, while the relationships between them are represented by lines, which are referred to as ties, edges, or arcs [47]. This study involved fifteen main actors. However, it was realized during the data collection process that in terms of communication, private firms were in touch with individuals/households through advertisements. Hence, to complete the network, a dummy variable for private individuals/households (PI) was introduced. There were thus sixteen nodes in the actor-network.

The relationship between the entities is measured in terms of frequency of contact or by criteria set by the researcher. This research employed two main criteria: magnitude and directionality. Magnitude refers to the frequency and strength of social interactions, while directionality refers to the flow or direction of the social interaction, in terms of where or from whom the interaction originated and to whom it is directed [48]. In this study, the magnitude was measured in terms of the exchange of information among actors concerning sustainable energy issues in the municipality. Directionality was measured in terms of where information usually originated from and to whom it was directed in the actor-network, and it was visualized with arrowheads in the diagram depicting the actor-network. 
During the interviews, actors were first asked to provide a brief description of the nature of their engagement in sustainable energy initiatives in the municipality. Subsequently, they were asked to indicate other actors that they engaged with (whether they exchanged information regularly or collaborated in sustainable energy projects) in the conduct of their activities. Based on these data and the criteria mentioned above, a data matrix was created where " 1 " and " 0 " were used to indicate whether or not there was a relationship between two actors, with " 1 " denoting the presence of a relationship and " 0 " denoting the absence of one. The data gathered from this assessment formed the basis of network visualization, which was done using the NetDraw component of the UCINET 6 software [49]. Centrality measures inherent in the NetDraw software were used in ascertaining core actors and mediators within the actor-network. Qualitative data obtained from the FGDs and key informant interviews were transcribed and imported into the Atlas.ti software, where codes were assigned to specific themes in each interview data. Outputs of the codes, with their corresponding quotations, were generated, and the patterns were used for analysis. The results were discussed and, where necessary, quotations were presented verbatim to support the findings.

\section{Results and Discussions}

Demographically, the FGD in the Busa community was made up of eight people (six males and two females) with an age range of 33 to 57 years, while the FGD in Guropisi was made up of six people (five males and one female) with an age range of 28 to 52 years.

\subsection{Local Actors Involved in Sustainable Energy Initiatives in the Wa Municipality}

The principal actors identified in the sustainable energy sector in the Wa municipality are local government agencies, NGOs, Ministries, Departments and Agencies (MDAs), and private sector organizations. The ensuing sub-section discusses the activities of the various actors in detail. The study revealed 13 main actors in sustainable energy initiatives in the Wa municipality (see Figure 2). Two beneficiary communities of sustainable energy projects were also included. Hence, a total of 15 actors were analyzed.

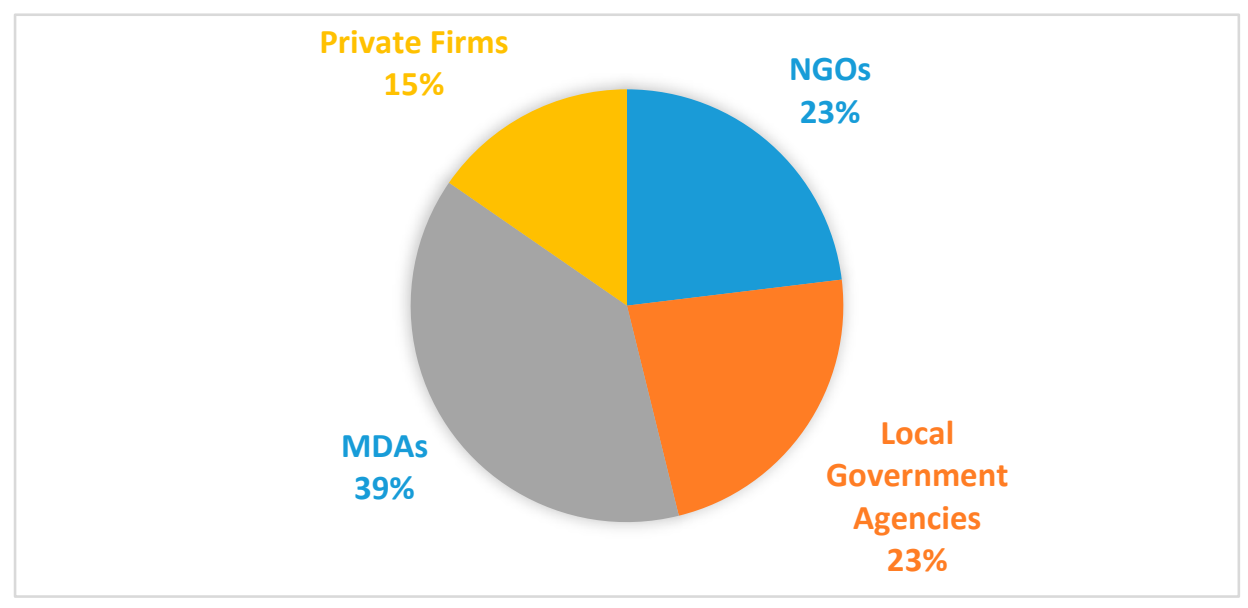

Figure 2. Key actors in Sustainable Energy Transition (SET) initiatives in the Wa municipality (Source: Authors' calculations).

The roles and types of initiatives vary between the actors in the municipality. While some actors' activities were primarily concerned with sustainable/renewable energy development and utilization, others were not directly focused on sustainable energies. An NGO such as WaterAid, for instance, primarily deals with providing clean water and sanitation services to communities. However, it relies on solar-powered water pumping systems in providing water to the communities, due to the unreliable nature of the electricity supply from the national grid. The Environmental Protection Agency (EPA) 
is particularly concerned with environmental conservation. It organizes programs to sensitize rural communities (especially women) regarding the sustainable use of fuelwood. It also undertakes woodlot projects across rural communities in the municipality. Additionally, the Statistical Service Department is primarily responsible for the collection, analysis, and dissemination of demographic data. Although its activities are not directly focused on sustainable energies, it collects and analyzes data on energy at the household level and makes these data available for planning and other purposes. An interviewee at the Statistical Service Department stated the department's key role with regards to energy as "By our mandate, we coordinate the production of all statistical activities in the country. So, we provide technical support to the Energy Commission in their statistical needs". The Regional Planning and Coordinating Unit (RPCU) coordinates the activities of the local government agencies, especially in development planning in the entire region. Hence, even though it is at the apex of the local government structure, it only coordinates, and does not initiate any, sustainable energy projects. WaterAid, the EPA, the Statistical Service Department, and the RPCU can thus be considered as secondary actors since their activities are not directly focused on the development and utilization of renewable/sustainable energies. Table 1 presents a summary of all of the actors and their activities as described in their interviews. 
Table 1. Types of local actors and the nature of their involvement in SET activities.

\begin{tabular}{|c|c|c|}
\hline Name of Actor & Type & $\begin{array}{l}\text { Description of the Actor's Role in the Planning and Implementation } \\
\text { of Sustainable Energy Initiatives }\end{array}$ \\
\hline $\begin{array}{l}\text { Regional Planning and } \\
\text { Coordinating Unit (RCPU) }\end{array}$ & Local government & $\begin{array}{l}\text { The RCPU is a unit of the RCC, which is at the apex of the local } \\
\text { government structure. It coordinates all of the development planning } \\
\text { and implementation activities of the Municipal Assembly and state } \\
\text { agencies within the Upper West Region. }\end{array}$ \\
\hline $\begin{array}{l}\text { Municipal Planning and } \\
\text { Coordinating Unit (MCPU) }\end{array}$ & Local government & $\begin{array}{l}\text { The MCPU is responsible for the planning and implementation of } \\
\text { development projects for all sectors (including energy) at the municipal } \\
\text { level. It also coordinates the activities of other decentralized } \\
\text { departments, NGOs, and private sector actors in the municipality. }\end{array}$ \\
\hline $\begin{array}{l}\text { Community Development } \\
\text { Department (CDD) }\end{array}$ & Local government & $\begin{array}{l}\text { The CDD is a member of the Municipal Planning and Implementation } \\
\text { Committee. It engages communities to get their needs for incorporation } \\
\text { into the municipal medium-term development plan. It also works with } \\
\text { NGOs in sustainable energy initiatives at the community level. }\end{array}$ \\
\hline $\begin{array}{l}\text { Statistical Service Department } \\
\text { (GSS) }\end{array}$ & State agency & $\begin{array}{l}\text { It is the government agency responsible for collecting and analyzing } \\
\text { statistical data for, and on behalf of, the government. It provides data } \\
\text { for planning at the local government agencies. It usually collects } \\
\text { household-level data, including data on various energy sources. }\end{array}$ \\
\hline Volta River Authority (VRA) & State agency & $\begin{array}{l}\text { The state agency is responsible for the generation, transmission, and } \\
\text { distribution of electricity (from both renewable and non-renewable } \\
\text { sources). }\end{array}$ \\
\hline $\begin{array}{l}\text { Environmental Protection } \\
\text { Agency }\end{array}$ & State agency & $\begin{array}{l}\text { The state agency is responsible for environmentally sustainable } \\
\text { development. It partners with NGOs to train local communities on the } \\
\text { sustainable use of fuelwood and also undertakes community-based } \\
\text { woodlot projects in the municipality. }\end{array}$ \\
\hline Ministry of Energy (MOE) & State agency & $\begin{array}{l}\text { Responsible for energy policy formulation, implementation, monitoring, } \\
\text { and evaluation, as well as the supervision and coordination of the } \\
\text { activities of Ghana's Energy Sector Agencies. Initiated an ICT project } \\
\text { which saw the installation of solar PV systems for } 25 \text { rural schools in the } \\
\text { Municipality. }\end{array}$ \\
\hline Energy Commission (EC) & State agency & $\begin{array}{l}\text { The state agency is responsible for the regulation, management, } \\
\text { development, and usage of energy resources in Ghana. It regulates the } \\
\text { electricity, natural gas, and RE industries in Ghana. }\end{array}$ \\
\hline PronetNorth & NGO & $\begin{array}{l}\text { An NGO focused on poverty reduction, gender equality, ecological } \\
\text { balance, and human dignity. It implements projects that enhance the } \\
\text { adoption of sustainable/renewal energy at the community level in the } \\
\text { municipality. }\end{array}$ \\
\hline $\begin{array}{l}\text { Netherlands Development } \\
\text { Organisation (SNV) }\end{array}$ & NGO & $\begin{array}{l}\text { An international NGO focused on poverty alleviation and improving } \\
\text { access to basic services such as energy, water, hygiene, and sanitation. It } \\
\text { has implemented sustainable cookstove projects across some rural } \\
\text { communities in the municipality. }\end{array}$ \\
\hline WaterAid & NGO & $\begin{array}{l}\text { An international NGO primarily focused on improving access to clean } \\
\text { water, toilets, and hygiene. Implements solar water pumping projects } \\
\text { for rural communities in the municipality. }\end{array}$ \\
\hline PUMPTECH & Private firm & $\begin{array}{l}\text { A private-sector firm that is involved in the sale and installation of solar } \\
\text { water pumping systems in the municipality. }\end{array}$ \\
\hline Best Solar & Private firm & $\begin{array}{l}\text { A private firm that is mainly involved in the sale and installation of } \\
\text { solar PV systems and applications. }\end{array}$ \\
\hline
\end{tabular}

Source: authors' conception.

\subsection{Sustainable Energy Actors' Network in the Wa Municipality}

The network of actors in the municipality is characterized by a wide range of interactions between NGOs, MDAs, private firms, local government agencies, and local communities (see Figure 3). Private firms are mainly contracted by either NGOs or state agencies to undertake installations of solar systems for them. Hence, the nature of the interaction (defined in the context of this study as the exchange of information and communication with regards to the development and utilization of sustainable energies) is mostly one-way, with the interaction often emanating from the NGOs or state agencies such as the Energy Commission. However, an interviewee at PUMPTECH, a private sector firm, indicated that their organization has presented its profile to the local government agencies, particularly the Municipal Planning and Coordinating Unit (MCPU) and the Community Development Department (CDD) so that they can be contacted in case their services are needed. Both private 
sector firms (Best Solar and PUMPTECH) are also constantly in touch with private individuals and households through advertisements. Hence, to complete the network, a dummy variable for private individuals/households (PI) was introduced. These private individuals are therefore not considered as major actors even though they form a part of the network. Data gathered from private firms indicate that clients are mostly institutions and NGOs, due to the high cost of solar systems. However, a few individuals who can afford the systems also form part of their clients. A respondent at PUMPTECH recounted that "... our clients are mostly NGOs because of the expensive nature of the solar systems. They include World Vision, UNDP, Community Water and Sanitation Agency (CWSA), FAO and a few private individuals who can afford it".

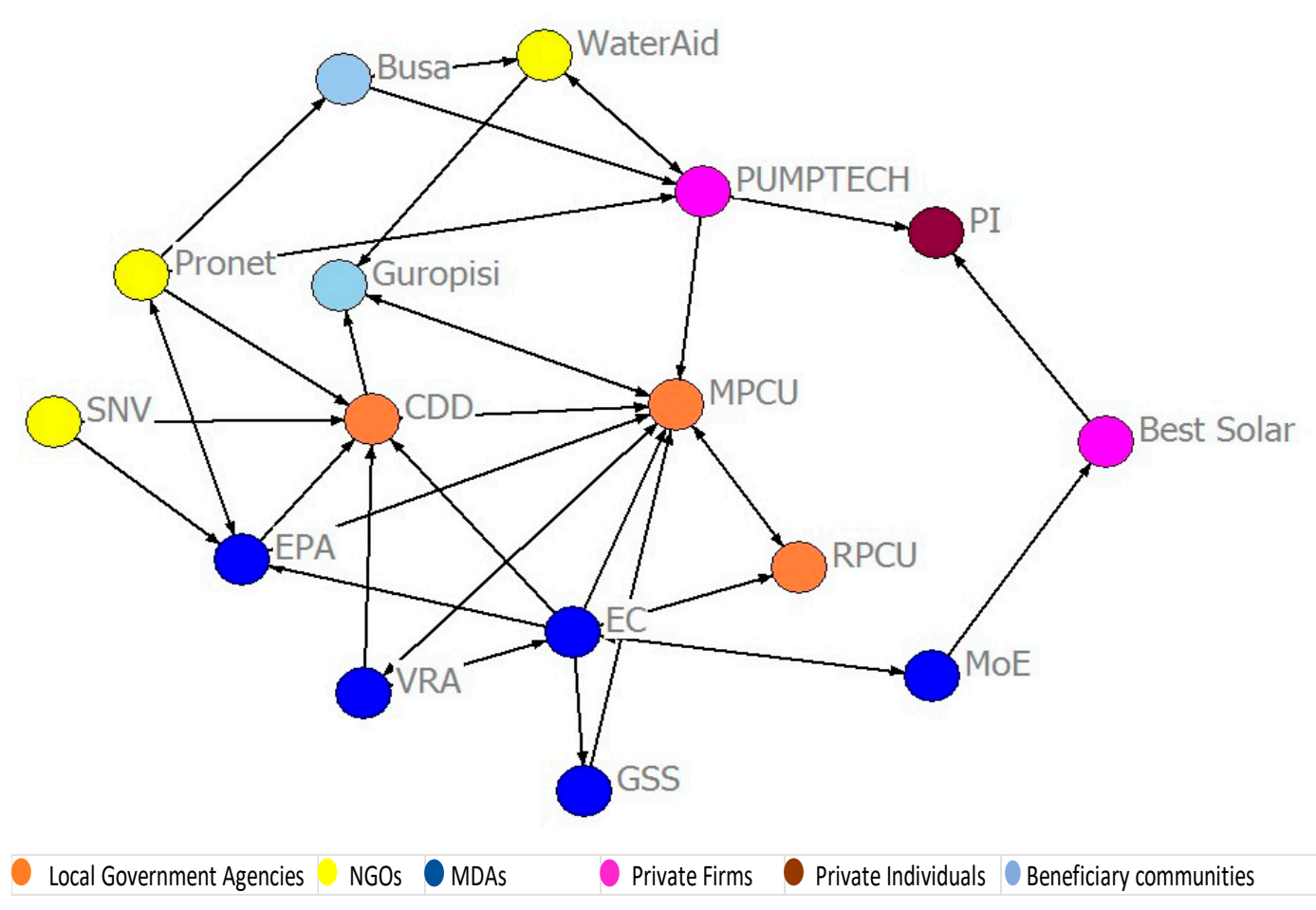

Figure 3. The sustainable energy actor-network in the Wa municipality (Source: Authors' conception, created with the NETDRAW component of UCINET 6 [49].

Figure 3 portrays a series of directional relationships between actors in the system; the arrowheads on lines indicate the directions of interactions. For example, there is a one-way interaction between the Energy Commission (EC) and the RCPU, the EC, and the MPCU, and the EC and the CDD, with the source of interaction being the EC. This relationship affirms the findings from the local government agencies, which indicated that they only get involved in the sustainable energy initiatives of the EC when they need to perform some functions for it. For instance, when asked whether they coordinate activities of the EC, an interviewee at the RCPU stated: " ... we only get involved if they are undertaking any projects that require our coordination or participation". Similarly, an interviewee at the CDD recounted that " ... unless the Energy Commission needs us to do something for them (like data collection), we usually don't do much on energy", whilst the MPCU indicated that it is mostly engaged by the EC in policy briefing meetings.

On the other hand, there are two-way interactions between agencies, such as between the MPCU and CDD, and between the RCPU and MPCU, mainly resulting from the coordination of development planning and implementation at the local level. The MPCU, for instance, relies on the CDD for community needs and aspirations, which it incorporates into the Medium-Term Development Plan (MTDP), while the RPCU coordinates the activities of the MPCU; hence, there is a constant interaction between these actors. Two-way interactions between state agencies such as the EPA and 
local government agencies such as the MCPU often result from collaborations on sustainable energy projects and also because the MPCU coordinates the developmental activities of all state agencies and decentralized departments at the local level. The MPCU also works hand-in-hand with the Volta River Authority (VRA) in extending electricity supply to communities within the municipality. Data gathered from the VRA indicate that the MCPU, with the aid of the CDD, often selects communities to which the national grid is to be extended for electricity supply. The VRA carries out such extension projects. The findings above support Foxon's [28] assertion that energy transition results from the interaction between elements such as institutions, business strategies, technology, and user practices. The actor-network shows that all actors in the municipality are, in one way or another, connected and that some of them do collaborate on sustainable energy projects.

\subsubsection{Core Actors within the Actor-Network}

Degree and eigenvector centrality scores were used to identify the core actors in the actor-network. Table 2 summarizes the scores of all centrality measures of the actors. The degree centrality scores from the actor-network show that the MPCU, CDD, and EC are core actors in the network, with degree scores of 8,7 , and 7, respectively. These scores imply that they have the highest number of connections in the actor-network. However, as noted by Hansen [50], degree centrality is merely an indicator of popularity and does not differentiate between quantity and quality. It simply measures the number of actors that a particular actor is connected to. Hence, the popularity of actors such as the MCPU and the CDD is primarily tied to the fact that most of the other actors in the network contact them before implementing their activities in the municipality. Based on the degree centrality scores, the least popular actors in the network are the RCPU, Statistical Service Department (GSS), Ministry of Energy (MOE), Netherlands Development Organisation (SNV), and Best Solar.

Table 2. Centrality scores for actors in the network.

\begin{tabular}{ccccc}
\hline \multirow{2}{*}{ Actor } & \multicolumn{4}{c}{ Centrality Measures } \\
\cline { 2 - 5 } & Degree & Betweenness & Closeness & Eigenvector \\
\hline RPCU & 2.00 & 0.00 & 34.00 & 0.18 \\
\hline MPCU & 8.00 & 29.85 & 23.00 & 0.46 \\
\hline GSS & 2.00 & 0.00 & 34.00 & 0.18 \\
\hline CDD & 7.00 & 16.92 & 25.00 & 0.43 \\
\hline VRA & 3.00 & 0.00 & 31.00 & 0.27 \\
\hline SNV & 2.00 & 0.00 & 38.00 & 0.16 \\
\hline PUMPTECH & 5.00 & 24.13 & 27.00 & 0.20 \\
\hline Pronet & 4.00 & 8.07 & 30.00 & 0.22 \\
\hline EC & 7.00 & 23.63 & 26.00 & 0.40 \\
\hline EPA & 5.00 & 7.72 & 28.00 & 0.35 \\
\hline WaterAid & 3.00 & 2.25 & 36.00 & 0.11 \\
\hline MOE & 2.00 & 8.50 & 36.00 & 0.09 \\
\hline Best Solar & 2.00 & 2.50 & 41.00 & 0.03 \\
\hline
\end{tabular}

Source: Authors' calculations.

The eigenvector centrality provides a better measure for identifying core actors in the network than the degree centrality (see Figure 4) since it not only considers the degree (number of connections) that an actor has but also the degree of the other actors that it is connected to [47]. Thus, despite having a low degree centrality, an actor could have a high eigenvector centrality if the other actors that it is 
connected to have higher degree centralities (more connections). From Table 2, it can be seen that even though actors such as the RCPU, GSS, MOE, SNV, and Best Solar all have degree centralities of 2, their eigenvector centralities differ, with the RCPU and GSS having the highest score of 0.18 . These scores imply that the RCPU and GSS are more popular actors than the MOE, SNV, and Best solar because many of the actors that they are connected to (such as the MPCU, CDD, EC, and PUMPTECH), have higher degree centralities, while the MOE, SNV, and Best Solar are connected to actors with lower degree centralities. PUMPTECH is more popular than its rival firm (Best Solar) and many of the NGOs because the firm does the installation of solar systems for several governmental and non-governmental organizations in the municipality. This is, in part, because the firm has submitted its organizational profile to local government agencies such as the MCPU and has Pronet North (an NGO which undertakes sustainable energy initiatives in the municipality) as its key partner.

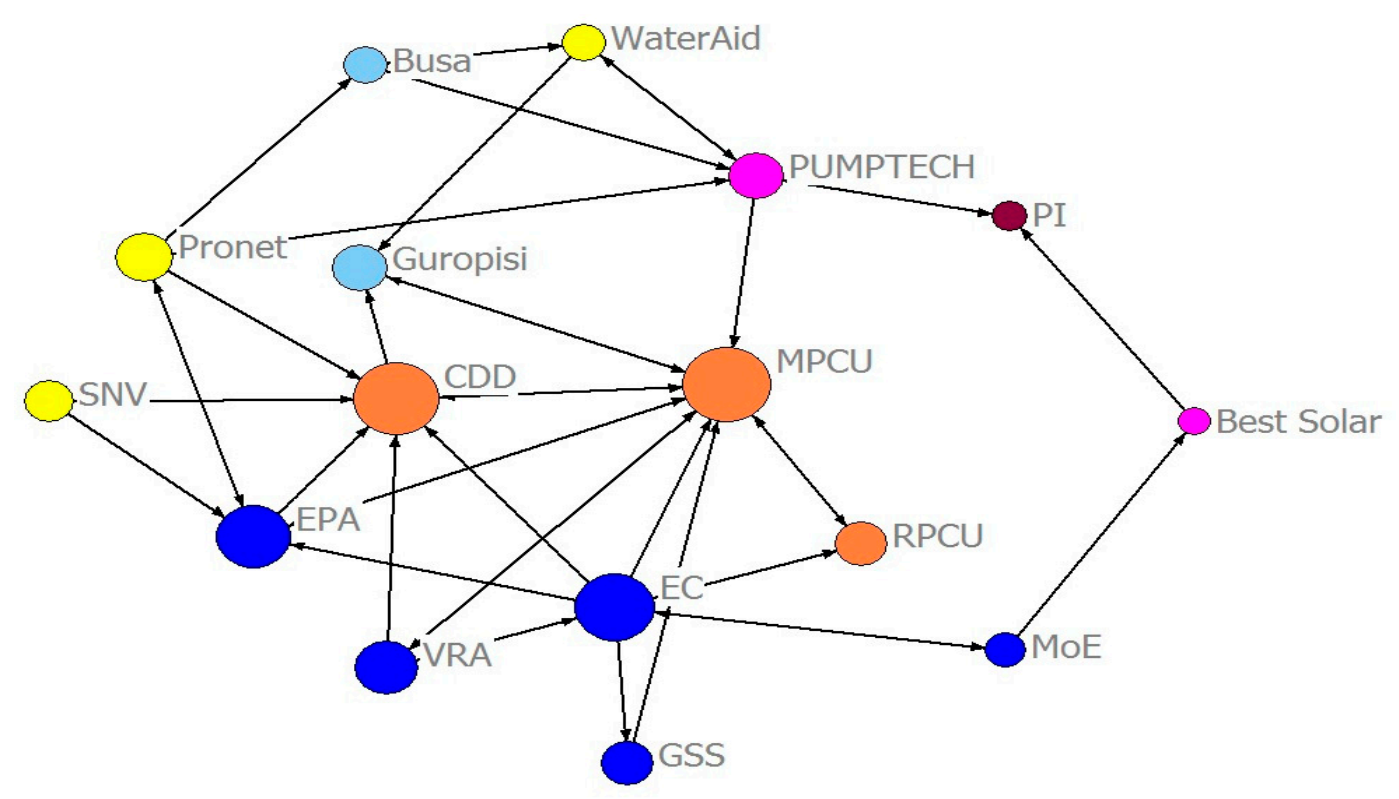

Local Government Agencies NGOs MDAs Private Firms

Figure 4. The eigenvector centralities of actors in the network (Source: Authors' conception, created with the NETDRAW component of UCINET 6 [49].

\subsubsection{Mediators within the Actor-Network}

Betweenness centrality helps to identify mediators within the actor-network. It indicates an actor's role in sharing information from one part of the network to another. The MPCU has the highest betweenness centrality, with a score of 29.85. Given its role in coordinating all developmental projects and activities of all other agencies in the municipality, the MPCU serves as an important connection between all actors. PUMPTECH is the second most popular mediator in the actor-network. The firm executes the projects of many actors, especially the NGOs, and serves as the implementational link between the local government agencies, local communities, and NGOs. For instance, after the installation of solar systems in local communities, the firm trains a few individuals at the community level to operate and undertake basic maintenance of the project. In the event of there being a major problem, the community members inform the firm, and if there is the need for changing some major components, the firm, in turn, asks the authorities in charge of the project for funds to buy and install the component. An interviewee at the firm stated "we train some people in beneficiary communities to operate and maintain the systems. But if there is a problem that is beyond their capacity, we send our technical team to work on it". The EC is also a principal intermediary in the actor-network. However, 
as seen in Figure 5, the EC connects only the state agencies and local government agencies, with a mostly one-way interaction, often originating from it, to the other agencies.

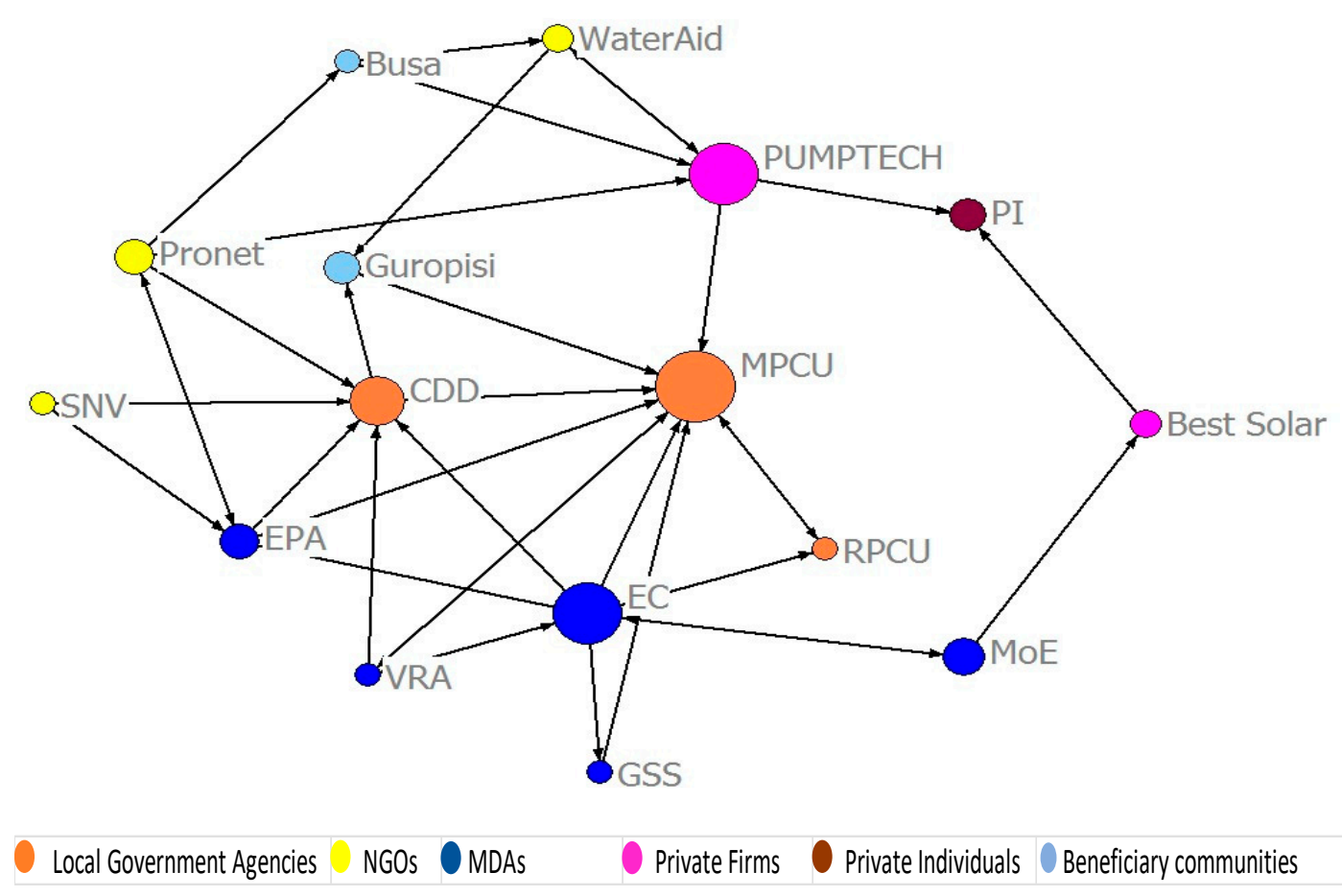

Figure 5. The betweenness centralities of actors in the network (Source: Authors' conception, created with the NETDRAW component of UCINET 6 [49].

Using the closeness centrality scores, it can be deduced from Table 2 that the MPCU, CDD, EC, and PUMPTECH are closer to all of the other actors in the network than the rest. According to Hansen et al. [50], a low closeness centrality score means that an actor is directly connected to or just a step away from most of the other actors in the network. On the other hand, a higher closeness centrality score implies that an actor is farther away from all of the other actors in the network.

Despite local government agencies being popular in the actor-network, results show that their involvement in sustainable energy planning and implementation is low. The only sustainable energy initiatives that they participated in were those initiated by the MDAs or NGOs. Hence, local government agencies themselves did not initiate or implement any sustainable energy initiatives of their own. Interviews with the RCPU, MCPU, and CDD all revealed that they only get involved when the Energy Commission needs them to perform a specific function or when an NGO or state agency is carrying out a project that requires their participation. A respondent at the CDD, for instance, recounted that the department only participated in collecting community-level data on energy consumption for the Energy Commission. When queried as to whether the department has ever participated in any sustainable energy-related initiative, the respondent indicated that "Yes. We administered questionnaires to gather data on energy consumption in the municipality. This was done for the Energy Commission". The MPCU's involvement in sustainable energy planning is also low as compared to its participation in other sectors such as health and education. A review of the 2010-2013 and 2014-2017 MTDPs of the municipality, for instance, found no projects on sustainable energy, even though projects on the electricity supply through the extension of the national grid were found. Data gathered from the MPCU show that despite having carried out an awareness program on renewable energy, the unit's limited involvement in the planning and implementation of sustainable energy initiatives is not because it cannot do so but rather because of the centralized nature of how such initiatives are carried out. An interviewee at the unit asserted that 
"We participate more often in sectors such as education and health than renewable/sustainable energy. It is not because we cannot do these things, it is because everything is done at the top. Even though issues of renewable energy are incorporated under the Infrastructure and Human Development dimension of the new Medium-Term Development Framework, it does not mention local government agencies as implementing or collaborating agencies (Respondent, MPCU)."

The respondent at the MCPU also added that incorporating sustainable energy projects into the municipal medium-term plan "is also a matter of priority and how the community sees it as a felt need". This statement suggests that perhaps sustainable energy is currently not a priority for the local government in the municipality. On the part of the communities, the non-recognition of sustainable energy as a felt need can be attributed to the low level of public awareness of renewable energy systems and their benefits in Ghana as a whole. Bensah et al. [51], and Hagan [52] identified inadequate public education and awareness of the various types and benefits of renewable energy technologies as a key policy gap in Ghana's RE sector. The low level of involvement of local government agencies in sustainable energy planning is also reflected in their lack of awareness of the Ghana Renewable Energy Master Plan. The plan was prepared in recognition of the fact that most renewable energy initiatives in the country are either pilot projects or are being carried out on short-term planning cycles [53]. Therefore, the plan has a principal objective of addressing this shortfall by providing a framework for the long-term promotion and development of Ghana's renewable energy resources. However, both the MPCU and the CDD were not aware of this plan, while an interviewee at the RCPU stated that "I have heard about it ... . but I don't know much about it". Even though the master plan mentions NGOs and private sector actors as key collaborators in its implementation, all of the NGOs and private sector actors in the municipality are either not aware of it or have only heard about it but do not know their specific roles in its implementation. In all, $69 \%$ of the actors are not aware of the plan, while $31 \%$ have only "heard about it". Inferring from the above discussions and findings, it can be deduced that local government agencies play a facilitative rather than a direct role in promoting sustainable energy initiatives. Bawakyilenuo et al. [54] explains that the role of local governments in promoting sustainable energy can be described as facilitative, where they do not have direct mandates and they undertake activities such as awareness creation. In the following section, we present the results from FGDs, shedding light on what happened in two cases: (i) a solar lighting project in Guropisi, Ghana; and (ii) a 780-watt solar water pumping scheme in Busa, Ghana.

\subsection{How Did it Happen? The Nature of Sustainable Energy Interventions in the Wa Municipality}

Results from FGDs in two beneficiary communities are presented in this section. Two beneficiary communities (Busa and Guropisi) of some sustainable energy projects were used as case studies to understand the nature of sustainable energy initiatives in the municipality. The FGD in the Busa community was made up of eight people (six males and two females) with an age range of 33 to 57 years, while the FGD in Guropisi was made up of six people (five males and one female) with an age range of 28 to 52 years.

\subsubsection{Case Study 1: A Solar Lighting Project in Guropisi}

Guropisi is a small rural community in the Wa municipality. The community is located in the north-eastern part (geographic coordinates 9.976984, -2.321265) of Wa, the municipal and regional capital on the Wa-Sandema road. In 2013, the Ghana Cocoa Board (COCOBOD) launched an initiative to supply solar street lights to cocoa, coffee, and shea nut growing communities across the country. Guropisi is one of the communities that benefited from the project, primarily because it was not connected to the national grid at that time. The project was delivered through the Wa Municipal Assembly, which installed seven solar street lights in the community. Participants of an FGD in the community indicated that the lights were strategically sited in the community based on clusters of houses. 
During its implementation, the community members provided manual labor, and after the installations were complete, a committee was set up at the community level to monitor and operate the lights. Apart from providing lighting at night, the project also yielded several benefits to the community members. A participant in the FGD is quoted saying " ... the lamps stopped theft cases in the community and also helped to prevent bad adolescent behavior among our children because the lights made it easier for them to be monitored at night". The participants recounted that before the solar street lights, theft cases were frequent in the community. A manifestation of these theft cases was evident in what remains of a solar water pumping system that was installed in the community. The community's only borehole was mechanized with a solar water pump and a storage tank to make access to clean water easier. However, the solar panel was stolen, and the borehole had to be returned to its initial state with a fitted handpump, from which drawing water is more laborious and time-consuming.

Despite the benefits that the lights brought to the community, all of the seven street lights installed in the community are currently non-functional. One of the project's committee members explained during the FGD that they were told during the installation of the project that the batteries of the solar street lights would last for five years hence; the current state of the lights is because the batteries' life span has elapsed. When asked whether they had reported the issue to the municipal assembly, the answer was "no", and when queried on why they had not reported the issue, one participant simply pointed to the transmission lines of the national grid that are currently running through the community. The community members never reported the non-functionality of the solar street lights to the authorities because they are now connected to the national grid and thus have no need for the solar street lights. The municipal assembly has also not followed up on the project to monitor the functionality of the street lights. This situation is a clear indication of the shortfalls associated with the ad-hoc nature of sustainable energy projects in the country. Since the project was not planned and implemented through the MTDP process of the municipality, no records of it were found in the projects nor the monitoring and evaluation sections of their 2010-2013 and 2014-2017 MTDPs.

The absence of the project in the MTDP perhaps explains why they have not followed up to monitor the project. Bawakyillenuo et al. [54] argued that local governments can monitor project implementation more closely and more quickly identify successes and failures than the central government. However, the findings above suggest that monitoring such projects becomes ineffective when they are not incorporated into local government plans. Ideally, once the community had been connected to the national grid, the street lights could have been fitted with new batteries and moved to other communities in the hinterlands that did not have access to electricity. The current situation in the community also highlights the problem of integrating on-grid and off-grid applications in terms of end-use. For example, since the solar street lights were already in the community, the national grid could have been connected only to the households without attaching any street lights to it. The solar street lights could have lit up the community at night while the grid electrification could have been used at the household level for in-house activities.

\subsubsection{Case study 2: A 780-Watt Solar Water Pumping Scheme in Busa}

Also located in the north-eastern (geographic coordinates 10.019271, -2.390471) part of Wa, Busa is a rural community with more than two thousand inhabitants. The community has a health center that relied on water from a manually-pumped borehole. A key informant from the community recounted that drawing water manually from the borehole made the delivery of healthcare at the health center very difficult. Midwives at the center, in particular, find it difficult, especially in times of childbirth, to get adequate water for their work. This situation made the leaders of the community come together with health workers at the center to find a solution to the problem. They set up a management committee for the health center, which is made up of 14 people (five females and nine males). The assembly member and two health workers were part of the committee. The committee requested WaterAid (an NGO) to assist them with a mechanized borehole at the health center. Their request was approved, 
and WaterAid decided to conduct a feasibility study of the project. After the feasibility study, it was decided that a solar water pumping system was best suited for the project, due to the unreliable nature of electricity from the national grid. WaterAid then contracted PUMPTECH to carry out the installation of the project.

In an FGD with some of the project's committee members, it was indicated that manual labor for the project was provided by the community members. The committee played a supervisory role in the project and is currently managing it. Some of the members of the committee have also been trained on how to operate the system. Participants of the FGD narrated that they had encountered no challenges with the project thus far and that the project had significantly improved healthcare delivery at the health center. Again, this project demonstrates that many sustainable energy initiatives do not originate from local government agencies. In this project, no local government agency was involved. The project was carried out by the community, WaterAid, and PUMPTECH.

\section{Conclusions}

The objective of this study was to analyze and understand the actors' engagement in sustainable energy initiatives at the local level. By applying the SNA method, we identified the most important actors in the local government units as being (i) the Municipal Planning and Coordinating Unit and (ii) the Community Development Department of the Wa Municipality in Ghana. Among the 16 nodes representing all of the actors involved in the study in the actor-network, these two local government units had the highest eigenvector centrality scores, of 0.46 and 0.43 , respectively. Our results show that their importance in the actor-network stems from the fact that they are the primary points of contact and conduits through which central government agencies and NGOs' projects are implemented locally. Additionally, based on the application of SNA, our analysis shows that these actors play an intermediary role by serving as the implementational link between the central government agencies, local communities, and NGOs. This study, therefore, has demonstrated the utility of the SNA method in (i) the identification of actors and (ii) enabling a better understanding of the complex, interwoven nature of actors' interactions.

Analysis of the local government agencies suggests that sustainable energy planning is centralized, with central government agencies such as the Energy Commission doing most of the work. Concerning their nature, sustainable energy initiatives at the local level are fragmented, with no proper planning or coordination through the District Medium-Term Development Planning process. As a result, projects are poorly monitored, posing a major challenge to their functionality and sustainability. A possible solution in the Ghanaian context appears to for the National Development Planning Commission and the Energy Commission to integrate sustainable energies into the local government planning process. The Energy Commission is also encouraged to liaise with local government agencies and NGOs to raise awareness of sustainable energies and their benefits at the local level. Consistent with prior research findings in the context of Europe, here, in the Ghanaian context, the role of local actors appears to be even more pronounced. With relatively limited resource availability, an improvement in actors' engagement (e.g., in planning and coordination activities) can improve the implementation and functionality of sustainable energy initiatives. Policymakers need to go beyond simplistic awareness campaigns towards the meaningful engagement of local bodies at the early stages of planning, as well as at the delivery and implementation stages. The governments might need to enact laws to facilitate the devolution of decision-making power to local bodies. Therefore, investing and building local capacity and the active engagement of local actors in sustainable energy projects could significantly energize the Ghanaian economy. Increased local ownership and employment can improve the livelihood and wellbeing of millions of people living in villages and remote areas in the African continent.

Overall, this study contributes, although modest, two important conclusions: (i) by explicitly considering local bodies as a socio-technical system and modeling actors' interactions, this study has identified the actors (i.e., who is involved) and has explained their roles (i.e., how they interact) in the success of local sustainable energy initiatives-this increased understanding of how actors interact 
in a socio-technical system adds to the body of knowledge about the MLP and the co-evolutionary approach; (ii) by demonstrating the utility of the SNA method in studying stakeholders' participation in the planning and implementation of sustainable energy initiatives locally. Our conclusions should be considered in the context of the various limitations this study faced. For instance, due to the limited availability of resources for fieldwork, this research could focus only on one municipality, the Wa municipality. While our findings can be fairly generalized for other municipalities, we do anticipate some differences in NGOs' involvement and the governments' selection of projects across various municipalities. Future studies could replicate this research by including more municipalities and local bodies. Before the implementation of any sustainable energy initiative locally, there is a need to ascertain the willingness to accept, and the ability to afford and utilize, renewable energy technologies of the users. Future research could, therefore, focus on the community acceptability and socio-economic determinants of sustainable energy usage at the local level.

Author Contributions: Conceptualization, M.M.A. and H.Q.-U.; methodology, M.M.A.; software, M.M.A.; validation, M.M.A., H.Q.-U. and A.K.; formal analysis, M.M.A.; investigation, M.M.A.; resources, M.M.A.; data curation, M.M.A.; writing — original draft preparation, M.M.A.; writing-review and editing, M.M.A., H.Q.-U., and A.K.; visualization, M.M.A.; supervision, H.Q.-U.; project administration, M.M.A. and H.Q.-U.; funding acquisition, M.M.A. All authors have read and agreed to the published version of the manuscript.

Funding: This research was funded by African Union Commission research grant for the master thesis at PAUWES, Algeria for the research work of Mark Akrofi and the APC was funded by York University, Canada and KFUPM, Saudi Arabia.

Conflicts of Interest: The authors declare no conflict of interest.

\section{References}

1. International Energy Agency. A Focus on Energy Prospects In Sub-Saharan Africa Africa Energy Outlook; International Energy Agency: Paris, France, 2014; Available online: https://www.lightingafrica.org/wpcontent/uploads/2016/07/141013_Africa_Energy_Outlook_Slides.pdf (accessed on 12 April 2019).

2. Melica, G.; Bertoldi, P.; Kona, A.; Iancu, A.; Rivas, S.; Zancanella, P. Multilevel Governance of Sustainable Energy Policies: The Role of Regions and Provinces to Support the Participation of Small Local Authorities in the Covenant of Mayors. Sustain. Cities Soc. 2018, 39, 729-739. [CrossRef]

3. Mey, F.; Diesendorf, M.; MacGill, I. Can Local Government Play a Greater Role for Community Renewable Energy? A Case Study from Australia. Energy Res. Soc. Sci. 2016, 21, 33-43. [CrossRef]

4. Lammers, I.; Hoppe, T. Analysing the Institutional Setting of Local Renewable Energy Planning and Implementation in the EU: A Systematic Literature Review. Sustainability 2018, 10, 3212. [CrossRef]

5. Johnson, O.; Nyambane, A.; Coy, E.; Oito, L.G. County Energy Planning in Kenya: Local Participation and Local Solutions in Migori County; Stockholm Environment Institute: Nairobi, Kenya, 2016; Available online: https://www.sei.org/mediamanager/documents/Publications/SEI-WP-2016-01-Kenya-county-energyplanning.pdf (accessed on 23 April 2019).

6. Sgouridis, S.; Csala, D. A Framework for Defining Sustainable Energy Transitions: Principles, Dynamics, and Implications. Sustainability 2014, 6, 2601-2622. [CrossRef]

7. Steg, L.; Perlaviciute, G.; van der Werff, E. Understanding the Human Dimensions of a Sustainable Energy Transition. Front. Psychol. 2015, 6, 805. [CrossRef]

8. Allwood, J.M.; Bosetti, V.; Dubash, N.K.; Gómez-Echeverri, L.; von Stechow, C. Glossary, Acronyms, and Chemical Symbols in In IPCC. Climate Change 2014: Mitigation of Climate Change. Contribution of Working Group III to the Fifth Assessment Report of the Intergovernmental Panel on Climate Change; Cambridge University Press: Cambridge, UK; New York, NY, USA, 2014.

9. Lockwood, M.; Kuzemko, C.; Mitchell, C.; Hoggett, R. Theorising Governance and Innovation in Sustainable Energy Transitions; EPG Working Paper 1304; University of Exeter: Exeter, UK, 2013; Available online: http://projects.exeter.ac.uk/igov/wp-content/uploads/2013/07/WP4-IGov-theroy-of-change.pdf (accessed on 24 April 2019).

10. Geels, F.W. From Sectoral Systems of Innovation to Socio-Technical Systems: Insights about Dynamics and Change from Sociology and Institutional Theory. Res. Policy 2004, 33, 897-920. [CrossRef] 
11. Foxon, T.J.; Hammond, G.P.; Pearson, P.J.G. Developing Transition Pathways for a Low Carbon Electricity System in the UK. Technol. Forecast. Soc. Chang. 2010, 77, 1203-1213. [CrossRef]

12. Verbong, G.P.J.; Geels, F.W. Exploring Sustainability Transitions in the Electricity Sector with Socio-Technical Pathways. Technol. Forecast. Soc. Chang. 2010, 77, 1214-1221. [CrossRef]

13. Fischer, L.B.; Newig, J. Importance of Actors and Agency in Sustainability Transitions: A Systematic Exploration of the Literature. Sustainability 2016, 8, 476. [CrossRef]

14. Cahn, M.A. Institutional and Non-Institutional Actors in the Policy Process. Public Policy Essent. Read. 2012, 2, 199-206.

15. Shannon, M.A. Mechanisms for Coordination. In Cross-Sectoral Policy Impacts between Forestry and Other Sectors; FAO: Rome, Italy, 2003; Available online: http://www.fao.org/3/Y4653E/y4653e08.htm (accessed on 23 April 2019).

16. Mirjat, H.N.; Uqaili, M.; Harijan, K.; Mustafa, M.; Rahman, M.; Khan, M. Multi-Criteria Analysis of Electricity Generation Scenarios for Sustainable Energy Planning in Pakistan. Energies 2018, 11, 757. [CrossRef]

17. Tsoutsos, T.; Drandaki, M.; Frantzeskaki, N.; Iosifidis, E.; Kiosses, I. Sustainable Energy Planning by Using Multi-Criteria Analysis Application in the Island of Crete. Energy Policy 2009, 37, 1587-1600. [CrossRef]

18. Pohekar, S.D.; Ramachandran, M. Application of Multi-Criteria Decision Making to Sustainable Energy Planning-A Review. Renew. Sustain. Energy Rev. 2004, 8, 365-381. [CrossRef]

19. Muntwyler, U. Towards 100\% Renewable Energy Supplies... In Proceedings of the 2015 10th International Conference on Ecological Vehicles and Renewable Energies, EVER, Monte-Carlo, Monaco, 31 March-2 April 2015. [CrossRef]

20. van Staden, M. Sustainable Energy Transition: Local Governments as Key Actors. In Towards 100\% Renewable Energy; Springer: Cham, Switzerland, 2017; pp. 17-25. [CrossRef]

21. Bawakyillenuo, S.; Agbelie, I.S. Ga East Municipality State of Energy Report 2014; Institute of Statistical, Social and Economic Research: Accra, Ghana, 2014; Available online: http://samsetproject.net/wp-content/uploads/ 2016/11/Ga-East-Municipality-State-of-Energy-Report-2014.pdf (accessed on 2 December 2018).

22. Fudge, S.; Peters, M. Motivating Carbon Reduction in the UK: The Role of Local Government as an Agent of Social Change. J. Integr. Environ. Sci. 2009, 6, 103-120. [CrossRef]

23. Bale, C.S.E.; Foxon, T.J.; Hannon, M.J.; Gale, W.F. Strategic Energy Planning within Local Authorities in the UK: A Study of the City of Leeds. Energy Policy 2012, 48, 242-251. [CrossRef]

24. O'Brien, G.; Hope, A. Localism and Energy: Negotiating Approaches to Embedding Resilience in Energy Systems. Energy Policy 2010, 38, 7550-7558. [CrossRef]

25. Tait, L.; Euston-Brown, M. What Role Can African Cities Play in Low-Carbon Development? A Multilevel Governance Perspective of Ghana, Uganda, and South Africa. J. Energy South. Afr. 2017, 28, 43. [CrossRef]

26. Geels, F.W. Technological Transitions as Evolutionary Reconfiguration Processes: A Multi-Level Perspective and a Case-Study. Res. Policy 2002, 31, 1257-1274. [CrossRef]

27. Turnheim, B.; Geels, F.W. Regime Destabilisation as the Flipside of Energy Transitions: Lessons from the History of the British Coal Industry (1913-1997). Energy Policy 2012, 50, 35-49. [CrossRef]

28. Foxon, T.J. A Coevolutionary Framework for Analysing a Transition to a Sustainable Low Carbon Economy. Ecol. Econ. 2011, 70, 2258-2267. [CrossRef]

29. Geels, F.W. Ontologies, Socio-Technical Transitions (to Sustainability), and the Multi-Level Perspective. Res. Policy 2010, 39, 495-510. [CrossRef]

30. Kemp, R.; Schot, J.; Hoogma, R. Regime shifts to sustainability through processes of niche formation: The approach of strategic niche management. Technol. Anal. Strateg. Manag. 1998, 10, 175-198. [CrossRef]

31. Geels, F.W.; Schot, J. Typology of Sociotechnical Transition Pathways. Res. Policy 2007, 36, 399-417. [CrossRef]

32. Papachristos, G.; Sofianos, A.; Adamides, E. System Interactions in Socio-Technical Transitions: Extending the Multi-Level Perspective. Environ. Innov. Soc. Transit. 2013, 7, 53-69. [CrossRef]

33. Smith, A.; Voß, J.P.; Grin, J. Innovation Studies, and Sustainability Transitions: The Allure of the Multi-Level Perspective and Its Challenges. Res. Policy 2010, 10, 435-448. [CrossRef]

34. Meadowcroft, J. Engaging with the Politics of Sustainability Transitions. Environ. Innov. Soc. Transit. 2011, 1, 70-75. [CrossRef]

35. Kern, F. Ideas, Institutions, and Interests: Explaining Policy Divergence in Fostering "system Innovations" towards Sustainability. Environ. Plan. C Gov. Policy 2011, 29, 1116-1134. [CrossRef] 
36. Fouquet, R. The Slow Search for Solutions: Lessons from Historical Energy Transitions by Sector and Service. Energy Policy 2010, 38, 6586-6596. [CrossRef]

37. Friedrich-Ebert-Stiftung and ILGS. A Guide to District Assemblies in Ghana, 2nd ed.; ILGS and Friedrich-Ebert-Stiftung Ghana: Accra, Ghana, 2016.

38. The Republic of Ghana. Local Government Act 1993; Republic of Ghana: Accra, Ghana, 1993; Available online: http://extwprlegs1.fao.org/docs/pdf/gha91927.pdf (accessed on 24 January 2019).

39. Farla, J.; Markard, J.; Raven, R.; Coenen, L. Sustainability Transitions in the Making: A Closer Look at Actors, Strategies and Resources. Technol. Forecast. Soc. Chang. 2012, 79, 991-998. [CrossRef]

40. Geels, F.W. A Socio-Technical Analysis of Low-Carbon Transitions: Introducing the Multi-Level Perspective into Transport Studies. J. Transp. Geogr. 2012, 24, 471-482. [CrossRef]

41. Izutsu, K.; Takano, M.; Furuya, S.; Iida, T. Driving Actors to Promote Sustainable Energy Policies and Businesses in Local Communities: A Case Study in Bizen City, Japan. Renew. Energy 2012, 39, 107-113. [CrossRef]

42. Yildiz, Ö.; Rommel, J.; Debor, S.; Holstenkamp, L.; Mey, F.; Müller, J.R.; Radtke, J.; Rognli, J. Renewable Energy Cooperatives as Gatekeepers or Facilitators? Recent Developments in Germany and a Multidisciplinary Research Agenda. Energy Res. Soc. Sci. 2015, 6, 59-73. [CrossRef]

43. Ruggiero, S.; Onkila, T.; Kuittinen, V. Realizing the Social Acceptance of Community Renewable Energy: A Process-Outcome Analysis of Stakeholder Influence. Energy Res. Soc. Sci. 2014, 4, 53-63. [CrossRef]

44. Creswell, J.W. Research Design: Qualitative, Quantitative and Mixed Approaches, 3rd ed.; SAGE Publications, Inc.: Newbury Park, CA, USA, 2009.

45. Ghana Statistical Service. 2010 Population and Housing Census Wa Municipality; Ghana Statistical Service: Wa Municipality, Ghana, 2014. Available online: http://www.statsghana.gov.gh/docfiles/2010_District_Report/ UpperWest/WAMUNICIPAL.pdf (accessed on 5 March 2019).

46. Wa Municipal Assembly. Medium Term Development Plan 2014-2017; Wa Municipal Assembly: Wa, Ghana, 2014.

47. Cronin, B. Getting Started in Social Network Analysis with NETDRAW; University of Greenwich: London, UK, 2015; Available online: https://core.ac.uk/download/pdf/74244341.pdf (accessed on 3 June 2019).

48. Xu, J.; Yang, R.; Wilson, A.; Reblin, M.; Clayton, M.F.; Ellington, L. Using Social Network Analysis to Investigate Positive EOL Communication. J. Pain Symptom Manag. 2018, 56, 273-280. [CrossRef] [PubMed]

49. Borgatti, S.P.; Everett, M.G.; Freeman, L.C. Ucinet for Windows: Software for Social Network Analysis; Analytic Technologies: Havard, MA, USA, 2002.

50. Hansen, D.L.; Shneiderman, B.; Smith, M.A.; Himelboim, I. Calculating and Visualizing Network Metrics. In Analyzing Social Media Networks with NodeXL; Morgan Kaufmann: Burlington, MA, USA, 2020; pp. 79-94. [CrossRef]

51. Bensah, E.C.; Kemausuor, F.; Antwi, E.; Ahiekpor, J. China-Ghana South-South Cooperation on Renewable Energy Technology Transfer Identification of Barriers to Renewable Energy Technology Transfer to Ghana; United Nations Development Programme: Accra, Ghana, 2015; Available online: https://www.undp.org/content/dam/ghana/docs/Doc/Susdev/UNDP_GH_SUSDEV_CG_Identification\% 20of\%20barriers\%20to\%20renewable\%20energy\%20technology\%20transfer.pdf (accessed on 14 May 2019).

52. Hagan, E.B. Renewable Energy Policy Review, Identification of Gaps and Solutions in Ghana Final Report; United Nations Development Programme: Accra, Ghana, 2015. Available online: http://energycom.gov.gh/files/Renewable\%20Energy\%20Policy\%20and\%20Regulatory\%20Gap\%20\% 20\%20\%20\%20Analysis\%20Final(2015).pdf (accessed on 10 March 2019).

53. Energy Commission. The Ghana Renewable Energy Master Plan; Energy Commission: Accra, Ghana, 2019. Available online: http://energycom.gov.gh/rett/phocadownload/remp/Draft-Renewable-Energy-Masterplan. pdf (accessed on 14 May 2019).

54. Bawakyillenuo, S.; Olweny, M.; Anderson, M.; Borchers, M. Sustainable Energy Transitions in Sub-Saharan African Cities: The Role of Local Government. In Urban Energy Transition; Droege, P., Ed.; Elsevier: Amsterdam, The Netherlands, 2018; pp. 529-551. [CrossRef]

(C) 2020 by the authors. Licensee MDPI, Basel, Switzerland. This article is an open access article distributed under the terms and conditions of the Creative Commons Attribution (CC BY) license (http://creativecommons.org/licenses/by/4.0/). 